\title{
Chinese Business Communication
}

\author{
Jiayi Wang
}

China officially opened its doors to the outside world in 1978, and since then, Chinese business communication has undergone tremendous development in terms of both frequency of use and influence. However, research on Chinese business discourse is still in its fledgling stage. This chapter begins with a brief review of the historical background of Chinese business communication and then moves onto an overview of the research on Chinese business discourse. Thereafter, it presents a case study that is based on corpus-assisted discourse analysis of the chairman's statement in Chinese annual reports. The chapter concludes with recommendations for further research.

\section{The historical background of Chinese business communication}

Historically, Chinese business communication has been particularly under-researched. This is partly because anti-commercial traditions dominated Chinese feudal society for several millennia. Based on imperial Chinese ideology, businesspeople were regarded as being at the lowest echelons of society according to the hierarchical social class structure. The following were the four major categories of people in descending order: 士 shi (scholars and officials), 农 nong (peasant farmers), 工 gong (artisans and craftsmen), and 商 shang (merchants). The earliest philosophical writings, the Analects of Confucius, made it clear that 小人喻于利 xiaoren yu yi li (the mind of the mean man is conversant with gain). Merchants who pursued profit were viewed with disdain, and business communication studies were not taken seriously.

Nevertheless, against the backdrop of significant sociopolitical changes in China over the past century or so, the evolution of Chinese business communication has begun to attract 
the attention of scholars, who have conducted a number of studies in Chinese and English (e.g., see Zhu and Li 2009 for an overview of studies conducted in Greater China). The influence of English business writing on Chinese business writing started during the period of the Opium War in 1841, when Chinese enterprises were forced to adapt to competition from foreign firms and powers (Zhang 2006). In 1873, the term 应用文 yingyongwen (practical genres) was introduced, reflecting the shift in focus toward business practices.

The economic reform of 1978 was another turning point. China shifted from a centrally planned economy featuring production for use to a socialist market economy featuring production for profit, a reduction in state control, and the introduction of market competition. This gave rise to changes in business discourse. Take, for example, the change in discourse patterns toward a more horizontal relationship in business writing. 上行 shangxing (a subordinate writing to a superior) and 下行 xiaxing (a superior writing to a subordinate) business letters, such as 请示 qingshi (requests) and 批复 pifu (official approval), were replaced by more 平行 pingxing (equals writing to each other) genres (Zhu $2000,2005)$ as a major means of written business communication.

\section{Chinese business communication research}

Research on Chinese business communication has been developing rapidly over the decades, benefiting from a wide spectrum of theoretical and methodological approaches. Theoretically, Chinese business discourse research has adopted a range of approaches, with systemic functional linguistics (including genre theory) and politeness theory being the most prominent.

Systemic functional linguistics is concerned with language use and function in particular social contexts. It analyzes the ways in which language serves specific social functions within particular genres. For example, drawing on the notion of theme, which is 
taken as the point of departure for writers who are attempting to project their perceptions of the reality of the experiential field onto their readers (Halliday 1994), Cheung (2011) compared 160 sales letters, of which 80 were in Chinese and 80 in English, and found a marked difference between them: The English corpus employed nearly two times more material processes (which refers to doing) as the theme than the Chinese corpus. Cheung (2011) suggested that this difference was related not only to grammatical dissimilarity but also to the English writers' more frequent attempts to trigger immediate purchase actions. Conversely, the Chinese writers were being subtler, which was possibly because in the Chinese culture, exerting direct pressure on the reader of promotion letters is potentially perceived as more face-threatening.

Within systemic functional grammar, genre theory is the most frequently applied in research on written Chinese business communication. Genre refers to a distinctive type of text, and it is understood as socially situated. Drawing on notions such as moves (Swales 1990), genre studies in Chinese business discourse research have tended to investigate the structural features of a specific text type on the basis of a corpus - that is, a collection of authentic texts. A number of genre studies have been conducted on Chinese sales letters, sales invitations, business faxes, and emails (e.g. Xiao 2011; Zhu 2000, 2005, 2013; Zhu and Hildebrandt 2013).

The most widely studied types of texts using genre theory are sales letters and sales invitations. Chinese sales letters appeared after the 1978 reform and are a genre that is still in development. Zhu and her colleague (Zhu 2000, 2005; Zhu and Hildebrandt 2013) analyzed authentic Chinese sales letters gathered from across mainland China, English letters from Australia and New Zealand (NZ), and evaluations of these letters by managers in China and NZ. They found several major differences. First, as illustrated by their example of an effective Chinese sales letter cited below, Chinese letters seem to have one extra purpose of 
establishing a long-term relationship with the reader. Second, the combination of greetings and introductory remarks were evident only in the Chinese letters. Third, English letters emphasize a positive image of the sales company, whereas, in addition to this, Chinese letters stress a respectful image.

\section{Example: An effective Chinese sales letter}

贵公司，

您好！工作一定很忙！

(Adadpted from Zhu 2000: 496)

\section{Translation:}

Honored company,

How are you? You must be very busy with your work.

(Adapted from Zhu 2000: 491)

This is a typical example of effective Chinese business letter writing; greetings and introductory moves — such as 'How are you? You must be very busy with your work' - do not exist in English sales letters. They are, however, common in private Chinese letters, and their application in sales letters reflects the Chinese tendency to emphasize relationship building. The business managers' evaluations and comments in the studies by Zhu and her colleague (Zhu 2000, 2005; Zhu and Hildebrandt 2013) also revealed that the Chinese managers focused more on building 情 qing (positive affect) with the reader, while the NZ managers sought a more immediate reaction to their sales pitch and informal engagement with the reader. These findings partly echo those of the study conducted by Cheung (2011), who applied Halliday's (1994) systemic functional theory, which we reviewed earlier. 
Unlike sales letters, Chinese sales invitations did exist before the 1978 reform; however, they have undergone significant changes. Before 1978, sales invitations tended to be written by superior organizations, which invited the subordinates to exhibitions for product distribution, stipulated by the hierarchical selling structure of the planned economy (Zhu 2005). After the economic reform, sales invitations were no longer confined to this hierarchy.

Similar to sales letters, Chinese sales invitations also pay significant attention to 关系 guanxi (relations). According to Zhu (2005), English invitations aim to portray a positive image, whereas Chinese invitations seek to portray a positive, collaborative, and respectful image and have the additional purpose of building a host-guest relationship with the reader. Below is the typical opening of an English invitation letter, followed by that of a Chinese invitation letter.

\section{The English invitation}

Dear Mr. L,

Here's your personal invitation to join 6000 fellow retailers, and 280 leading industry suppliers enjoying the Christmas Stocking Fair experience. (Zhu 2005: 1)

\section{The Chinese invitation}

敬启者，

中国经济急速发展, 各工商业必须提高其技术以增强本身的竞争力。为 满足有关工商业之要求, “X 展览会” 将于十二月份在北京举行。我司诚意邀 请贵公司派员前往参观。(Adapted from Zhu 2005: 204)

Translation:

Respected Reader, 
The Chinese economy is developing rapidly. Every industry or business has to

promote its technology to increase its competitiveness. In order to meet the needs of

the industries and businesses concerned, 'X Fair' is to be held in December in

Beijing. We sincerely invite your company to participate. (Adapted from Zhu 2005:

As can be seen, English sales invitations are usually shorter than their Chinese counterparts. Similar to sales letters, before actually issuing the invitation, Chinese sales invitations also tend to include introductory moves, such as those marked out in the example above, but they do not occur in English letters. This difference in generic structures is related to the variation in preferred information sequencing (Kirkpatrick 1993; Richard and McFadden 2016). Modern Chinese discourse has a tendency to follow the BECAUSE THEREFORE sequence, placing reasoning before the main statement. It is generally believed that the build-up to the main statement is equally important as, if not more so than, the statement itself, such as a request or an invitation. This is primarily because the preamble can do facework (Kirkpatrick, 1993) and help build a relationship. For example, Richard and McFadden (2016) examined American and Chinese employees' reactions to relationshipbuilding statements or what is termed facework (e.g., I hope all is well) and message structure (i.e., the placement of reasoning either before or after the request itself) in English business emails. They found that the Chinese employees reported a greater desire to do business with the sender of an email that included facework and placed reasoning before the request, whereas the American employees were more annoyed by this type of email.

Besides using systemic functional grammar, including genre theory, scholars of Chinese business communication have often applied politeness theory to investigate both written and spoken discourse. Taking as the point of departure the Cooperative Principle 
(Grice 1975), which states that when we communicate, we assume that the speakers and the hearers will cooperate during the conversation, Brown and Levinson (1987) proposed their seminal theory of linguistic politeness. This theory conceptualizes politeness as the expression of the speaker's intention to mitigate certain face-threatening acts (FTA) toward the hearer. According to Brown and Levinson, the speaker's choice of politeness strategy is affected by three sociological variables: the social distance between the speaker and the hearer, the power difference between the speaker and the hearer, and the rank of imposition of an FTA.

Xiao (2011) used politeness theory to analyze the request strategies in 280 business emails collected from three international trade companies based in China. These emails were exchanged between the Chinese firms and their overseas buyers and sellers before they struck a deal; therefore, the messages were primarily requests for information and the replies to these. Requests are seen as FTAs because they obstruct the freedom of the hearer. Xiao regarded the buyer as having positive power and the seller as having negative power; this is because China's foreign trade industry in particular has already become a buyer's market, in which supply exceeds demand. Xiao defined social distance as familiarity. Her findings suggested that due to the consideration for efficiency of communication in international trade, requests in the business emails generally tended to be direct, and power relations and social distance had no significant impact on the choice of politeness strategies.

Similarly, Yeung (1997) examined polite requests in business correspondence in the form of 360 English and 181 Chinese letters and memos, which were collected from a wide spectrum of commercial organizations in Hong Kong, including utility companies, banks, and hotels. Utilizing the three factors in Brown and Levinson's (1987) politeness theory, she found that only the factor of imposition was shown to have a statistically significant effect on the choice of polite expressions in the English data, but none of the factors, either alone or 
combined, had any significant impact on politeness choice in the Chinese business correspondence. Yeung (1997) explained the differences from a sociocultural perspective. For example, the Chinese may not interpret imposition in the same way as people in the English-speaking world. When making requests, the Chinese are 'debt-sensitive rather than debt-aversive', and the principle of reciprocity reduces the burden of imposition when the requests that are made are appropriate (Yeung 1997: 519).

More recently, Brown and Levinson's (1987) politeness theory has been expanded as a result of a further look at the key notion of face and discursive practices in context (the Linguistic Politeness Research Group 2011). Researchers have employed conversation analysis (CA)-informed approaches to examine spoken Chinese business discourse in situ. For example, through a fine-grained analysis of face practices, Chang and her colleague (Chang 2016; Chang and Haugh 2013) demonstrated the importance and complexity of face in intracultural Chinese business interactions in Taiwan.

Likewise, Li, Zhu, and Li (2001a, 2001b) employed CA, combined with ethnographic observations and follow-up interviews, to scrutinize the final five minutes of an intracultural and an intercultural business negotiation. Through a detailed analysis of one sequence during the closing stage of a negotiation amongst four Chinese businesspeople in mainland China, Li et al. (2001b) demonstrated the ways in which the Chinese speakers, who had differing interests and objectives, worked together to achieve conversational coherence, which contributed to the harmonious relationship that they were striving to attain. The authors ( $\mathrm{Li}$ et al. 2001b) noted that, unlike the business negotiations with which they were familiar in Britain, the Chinese participants did not go through the key points of the discussion and summarize them; rather, they made small talk beyond the topic at hand and co-constructed a coherent 'story line'. Li et al. (2001b) explained this using the key Chinese cultural concept 和 he (harmony). 
Another study by Li et al. (2001a) examined the closing stage of an intercultural negotiation between a native British English-speaking businessman and three of his Englishspeaking Chinese counterparts. It was found that the Chinese businessmen used a high involvement style and paid significant attention to non-task relationship creation through small talk before turning the conversation to business. The British businessperson commented that despite being familiar with 'the blurring between business and non-business matters', he still had problems with it:

Everything seems to take a long time. I'm used to that now, but I'm still having a little trouble with what we've agreed, or not agreed for that matter. They talk a lot, about nothing really. At the end of the day, I want to go home and tell my colleagues, yes we have a deal.

(Li et al. 2001a: 144)

Despite an increase in the sheer number of intercultural business discourse studies, similar to Li et al.'s (2001a) study referred to earlier, most of these studies have examined interactions using English as the medium of communication. Meanwhile, the real business world is witnessing a remarkable increase in the use of Chinese as a second language (L2), but this has rarely been studied (one exception is Du Babcock and Babcock 1996). The use of L2 Chinese in business communication warrants more research in the future.

Overall, business discourse is still a relatively new hybrid research field (BargielaChiappini, Nickerson, and Planken 2013). The first part of this chapter provided an overview of existing Chinese business discourse studies, which have applied a range of theoretical frameworks-with systemic functional linguistics (including genre theory) and politeness theory being the most prominent. The next section presents a case study of authentic managerial discourse. 


\section{The chairman's statement in annual reports: A corpus-assisted}

contrastive analysis

Given the small number of studies of Chinese business discourse using corpus analyses and the increasing attention that is being given to multimethod research, the second part of this chapter reports on a case study of corpus-assisted contrastive analysis of the chairman's statement in Chinese and English annual reports, with a focus on the Chinese discourse. It explores the main differences in the discursive patterns of this particular type of managerial foreword. A corpus of the chairman's statements in the annual reports of the Chinese company Sinopec was compared with an English corpus of the chairman's/chair's messages in the annual reports of the British-Dutch company Shell, with the aim of highlighting the distinctive features of the Chinese texts.

中国石化 zhongguo shihua (Sinopec) is a state-owned Chinese oil and gas company. Ranked among the top five Fortune Global 500 companies since 2011, it is the highestranking company in China (Fortune, 2017). Royal Dutch Shell was chosen because it matches Sinopec in terms of size and industry, with the former being the largest oil and gas company based in Europe and the latter the biggest in Asia. Both companies operate in the areas of exploration and production, refining, distribution and marketing, and petrochemicals, among others.

The type of executive messages in the annual reports that will be examined in this study encompasses texts that appear with a variety of labels, such as 'Chairman's Message' (Shell annual reports 2009-2015), 'Chair's Message' (Shell annual report 2016), and 'Chairman's Statement' (董事长致辞, dongshizhang zhici, Sinopec annual reports 20072016). Despite the various labels that have been employed, the study uses the chairman's statement as the generic label, as it has often been used (De Groot, Korzilius, Nickerson and Gerritsen 2006). 


\section{Data and methodology}

To investigate the discursive patterns of the Chinese chairman's statement, I reviewed the chairman's messages from Sinopec's original annual reports in Chinese, as well as those from Shell's original annual reports in English over the past decade - that is, the period spanning 2007 to 2016. This resulted in two specialized corpora, each of which comprised 10 statements. The Chinese texts contained over 2,018 word types and 11,289 word tokens, and the English texts contained 1,572 word types and 7,472 word tokens.

Regarding the overall methodology, this case study adopted the corpus-assisted discourse analysis approach (see Partington 2008 for an overview), combining the quantitative approach of conducting statistical overviews of the discourse with the qualitative approach of performing a discourse analysis that examined in detail particular stretches of texts that were of interest to the researcher. This corpus was analyzed using (a) the qualitative research software NVivo for qualitative content analysis and (b) the corpus analysis software AntConc (Anthony 2016). With regard to (b), a variety of corpus tools-including frequency checks, clusters, collocates, and keyword lists—-were used to examine the texts. For example, the unusually frequent words in the Chinese corpus were investigated via keyword lists. To do this, the Sinopec corpus was compared with a reference corpus: the Lancaster Corpus of Mandarin Chinese (LCMC), which is a one-million-word balanced corpus of written Mandarin Chinese created by McEnery and Xiao (2004). It is pertinent to note here that keywords are the words whose frequency is unusually high in the specialized corpus compared to the general reference corpus, which is the LCMC in this case. The corpus software AntConc Version 3.4.4 (Anthony 2016) was employed to produce the keywords (see Table 2).

Overall, three main discursive differences between Sinopec's and Shell's chairman's statements emerged from the data. First, the Chinese statements often began with thanks prior to reviewing the year, whereas the English statements tended to immediately summarize and 
reflect on the year. Second, the Chinese statements were more politically salient than the English texts. In particular, the Chinese messages were often positioned within China's political rhetoric at that time, such as Xi Jinping's 'Chinese dream' in the 2015 annual report. Third, when the company itself was referred to in the chairman's statement, Sinopec and Shell employed different means to construct authority.

\section{Opening the chairman's statement with thanks}

The first major difference lies in the opening of the chairman's statement. Sinopec often started the main body of text by expressing gratitude to shareholders and the wider community for their care and support.

Example 1 Chinese opening of the Chairman's statement (Sinopec 2013)

\begin{tabular}{|c|c|}
\hline Text & Generic Structure \\
\hline $\begin{array}{c}\text { 董事长致辞 } \\
\text { (Chairman's Statement) }\end{array}$ & Title \\
\hline $\begin{array}{l}\text { 尊敬的各位股东: } \\
\text { (Respected shareholders) }\end{array}$ & Salutation \\
\hline $\begin{array}{l}\text { 首先, 我谨代表中国石化董事会向各位股东和社会各界对本公 } \\
\text { 司的关心和支持表示衷心感谢。 } \\
\text { (First, I, on behalf of the Sinopec Board of Directors, would like to } \\
\text { express sincere gratitude to all the shareholders and various sectors } \\
\text { of the society for your care and support to our company.) }\end{array}$ & $\begin{array}{l}\text { Preamble } \\
\text { (Expression of } \\
\text { gratitude to } \\
\text { shareholders and } \\
\text { the wider society) }\end{array}$ \\
\hline $\begin{array}{l}2012 \text { 年面对极其困难的国际宏观经济形势以及复杂多变的石 } \\
\text { 油、石化市场环境，公司及早谋划….... } \\
\text { (In 2012, faced with an extremely difficult macroeconomic situation } \\
\text { globally and a complex and changeable oil, petrochemical market } \\
\text { environment, the Company planned early...) }\end{array}$ & $\begin{array}{c}\text { Review of the } \\
\text { year } 2012\end{array}$ \\
\hline
\end{tabular}


Example 1 is a typical opening that is used in the Chinese statements. The title is followed by a salutation, which clearly shows that Sinopec shareholders constitute the target audience of the message. After the salutation, the main body of the text begins by thanking the shareholders and 社会各界 shehui gejie (various sectors of the society). It then moves on to review the year 2012. Now, let us compare this with the typical opening of an English statement.

Example 2 English opening of the chairman's statement (Shell 2013)

\begin{tabular}{|l|c|}
\hline \multicolumn{1}{|c|}{ Text } & Generic Structure \\
\hline \multicolumn{1}{|c|}{ Chairman's message } & Title \\
\hline In 2012, we continued to deliver on our strategy in the face of an & \\
close attention to short-term economic conditions, but we take a & Review of the year \\
long-term, strategic view of the Company's development. We & 2012 \\
continue to invest in, and maintain, a diverse portfolio of assets, \\
despite economic headwinds.
\end{tabular}

In terms of the generic structures, notable differences exist. The generic structure refers to the way in which 'a particular genre develops typical and recognizable organizational structures' (Wang 2004: 75). The table below summarizes the generic structures of the Chinese and English texts in the corpora.

Table 1 Summary of generic structure (GS)

GS of Chinese chairman's statements (10) GS of English chairman's statements (10)
Title (10) Title (10)

Salutation (10) 
Expression of gratitude (9)

Body of the statements (10) Body of the statements (10)

Sign-off (10)

Sign-off (10)

The Chinese and English chairman's statements share a number of obvious similarities in terms of generic structures, but recurrent differences exist. The Chinese statements in the annual reports consistently begin with a salutation and, more interestingly, an expression of gratitude, whereas the English chairman's messages immediately address the theme - that is, a review of the year.

In the Sinopec statements, thanking the recipient of the message seems to be a formulaic move. In the Chinese corpus, seven annual reports-2007, 2008, 2009, 2012, 2014, 2015, and 2016-used “向列/各位股东与社会各界对公司的关心和支持表示衷心感谢!’ (express sincere gratitude to all the shareholders and various sectors of the society for your care and support to our company). Three other annual reports—2010, 2011, and 2013modified the expressions only slightly. In general, opening the chairman's statement with thanks emerged as a recurrent discursive pattern. This finding is reminiscent of Zhu's (2005) comparative work on Chinese and English sales invitation letters that we reviewed earlier; she found that the Chinese prefer to include introductory moves before actually issuing the invitation. Similarly, the introductory move of thanking the recipient of the message in the Chinese managerial forewords constitutes a preamble to the review, which builds rapport with the reader and aims to establish a positive and respectful public image of the company. 


\section{The Chinese chairman's statement: Where commercial and political slogans}

meet

The second major difference between the Chinese and English messages pertains to the political saliency of the texts. In this study, political saliency refers to the use of politically salient words and clusters in the particular type of business discourse under discussion.

Significantly, the findings suggest that, unlike Shell's chairmen, the Sinopec chairmen tended to embed political expressions in their written business discourse that is being examined here. Each mention of a political expression/slogan that could be clearly traced back to the Chinese government's political rhetoric in its official documents was counted numerically once. Overall, there were 105 mentions of salient political expressions in the Chinese corpus: five mentions in the 2007 annual report, eleven in 2008, nine in 2009, seventeen in 2010, nine in 2011, six in 2012, nine in 2013, fifteen in 2014, seven in 2015, and nineteen in 2016. The political expressions used in the Chinese business discourse tended to keep changing with the times. They were often taken directly from the top political documents of the then administration, and woven into the chairman's statements.

Take the closing of the chairman's message as an example: Although similar to most of the English statements, the Chinese statements often also ended with an expression of determination to develop the company further, and the Chinese closings tended to be positioned according to the Chinese central government's political agenda during that period. For instance, in the 2014 report, which was published in 2015, the chairman concluded his message with ‘我希望也相信 ... 中国石化必将 ... 为实现我们的石化梦、中国梦和建设 更美好世界做出新的更大的贡献' (I hope and believe ... Sinopec will surely ... make a new and bigger contribution to the realization of our petrochemical dream, Chinese dream, and the building of a better world). The term 'petrochemical dream' was coined based on the overarching political slogan 中国梦 zhongguo meng (Chinese dream) that followed it in the 
text. The 'Chinese dream' was a new term put forward by President Xi Jinping in late 2012; however, the government soon moved it to the top of its political agenda.

Sometimes the political expressions were even taken from the top government documents published in that particular year, as illustrated in Example 3 below.

\section{Example 3 An extract containing the word 发展 fazhan (development)}

根据中国政府确定的「十二五」规划纲要......本公司确定了「十二五」发展思 路, 即以科学发展为主题, 以加快转变发展方式为主线... (Sinopec, 2010 annual report, published in 2011)

According to the Twelfth Five-Year Plan set by the Chinese government . . . this company confirmed the development thinking for the Twelfth Five-Year Plan. That is, (the company) takes scientific development as the main theme and accelerates the transformation of the development mode as the main line ... (Author's translation)

In this example, the extract above highlights the political expression ‘以科学发展为 主题, 以加快转变发展方式为主线, which contains the Chinese keyword 发展 fazhan. It is a political slogan put forward by the Chinese government in its outline for the Thirteenth Five-Year Plan for the country (The Fifth Plenum of the 17th Central Committee of the Communist Party of China 2010: 3).

This finding of political saliency was also supported by keyword analysis. Keywords in corpus linguistics are words whose frequency of occurrence in a specific corpus exceeds that of chance alone, and they are 'likely to be of linguistic interest in terms of the text's aboutness and structuring, and which can be expected to repay further study' (Scott 2009: 80). The tool settings for undertaking the keyword analyses were as follows: a) negative keywords (words that are unusually infrequent) to be excluded; b) the keyword generation 
method: log likelihood (LL), which is the most commonly used method; and c) the threshold value: top 100. The top non-grammatical keywords of the two corpora are presented below.

Table 2 Key lexical words in the two corpora (keyness calculated using LL)

\begin{tabular}{|l|l|l||l|l|}
\hline & \multicolumn{2}{|c||}{ Chinese Keywords } & \multicolumn{2}{c|}{ English Keywords } \\
\hline No. & Keyword & Frequency & Keyword & Frequency \\
\hline 1 & 公司 (company) & 249 & our & 138 \\
\hline 2 & 本 (this) & 95 & we & 128 \\
\hline 3 & 董事会 (board of directors) & 92 & energy & 101 \\
\hline 4 & 股东 (shareholder) & 84 & gas & 70 \\
\hline 5 & 石化 (petrochemical/s) & 76 & world & 47 \\
\hline 6 & 发展 (develop/development) & 201 & shell & 45 \\
\hline 7 & 推进 (push forward) & 67 & global & 41 \\
\hline
\end{tabular}

Table 2 comprises the most exceptionally highly frequent content words in the Chinese corpus of Sinopec's chairman statements compared to the Chinese reference corpus, the LCMC, and those in the English corpus of Shell's chairman statements compared to the English reference corpus which is the British National Corpus (Leech, Rayson, and Wilson 2001). Most of these words are centered on the company and business, which is logical if one considers the nature of the texts. However, two Chinese keywords in the list may merit our attention—namely, 发展 fazhan (develop/ment) (which ranked number 6 in the list) and 推进 tuijin (push forward) (which ranked number 7). A closer examination of the Chinese texts showed that 发展 fazhan, especially 推进 tuijin, often formed a part of political phrases, which is consistent with the findings of Qian \& Tian's (2014) corpus-based study of China's government work reports.

Overall, politically salient expressions were found only in the Chinese chairman's statements. The political saliency of the Sinopec data is related to the firm's background. The company sits at the top of China's state-owned corporate hierarchy, and the Chinese 
government has made it clear that oil is the lifeblood of the country's economy, which implies its political influence on the operations of the business.

\section{How to refer to the company: The construction of authority}

The third major difference between the Chinese and English corpora relates to the ways in which the chairman refers to his company in his statement. This was first identified based on the results of the keyword analysis. As is evident in Table 2, the key lexical words of the two corpora in the section above一公司 gongsi (company), 本 ben (a formal way of saying 'this'), 'our', and 'we'-were the top two most unusually frequent words in the Chinese and English corpus, respectively. The collocations were then investigated through concordancing and the texts were revisited. Noticeable differences were found in the use of reference words.

With respect to the distribution of reference words used to indicate Sinopec in the Chinese corpus, on the whole, the most popular reference words were (a) 公司 gongsi (company) with no articles and (b) 本公司 ben (this company). In the Chinese language, nouns can be used without articles when they refer to specific objects. Therefore, in this case, the Chinese writers and readers know that 公司 gongsi refers to Sinopec, and it can be translated as 'the company' in English, which was mentioned only twice in the English corpus. What is more intriguing is the second most frequent reference word一本公司 ben gongsi. This reference word comprises 本 ben (this) and the noun 公司 gongsi (company). It is a very formal way of saying 'this company' that is often used in written business discourse to create a neutral and respectful image of the company. However, this did not occur in the English corpus.

With respect to the ways in which the Shell chairmen referred to Shell in their statements over the past decade, the nonperson reference form 'the company' was employed only twice in 2012, whereas the pronoun 'we' and possessive determiner 'our', which did not 
occur frequently in the Chinese corpus, topped the chart. The quoted texts in Example 4 below are typical of this recurrent difference in context.

Example 4 The beginning of the main body of the chairman's statement in the 2015 annual report

Sinopec: 2015 年, 全球经济复苏乏力, 中国经济增速放缓, 国际油价屡创新低, 境内 石油石化产品需求疲弱。面对异常艰难的生产经营形势，公司充分发挥... In 2015, there was a lack of momentum in the global economic recovery, Chinese economic growth slowed down, global oil prices repeatedly hit new record lows, and the domestic demand for oil and petrochemical products was weak. Faced with an extraordinarily difficult situation with regard to production and operation, the company gave full play to ... (Author's translation)

Shell: There is no doubt that 2015 was a turbulent year, with low oil and gas prices having a far-reaching impact on the energy industry. We have taken the opportunity to strengthen ...

In the above example, Sinopec used a nonperson form, whilst Shell employed the institutional pronoun we to refer to the company. A close reading of the corpora reveals that, generally speaking, the Chinese executive messages tended to use nonperson reference forms - that is, 本公司 ben gongsi and 公司 gongsi-to refer to Sinopec; this may create a neutral image of the company, thus reinforcing its professional identity as China's largest stateowned enterprise. The English statements, however, tended to utilize the 'institutional we' to refer to Shell, which also seemed to have the aim of maintaining professional distance, thus 
creating a professional identity for the company (Planken 2005). Despite this difference in forms, both can be seen as a discursive strategy to construct authority (Baym 2000).

In summary, drawing on corpus-assisted contrastive analysis, this study investigated the main differences in the discursive patterns between the Chinese and English chairman's statements in annual reports, with a focus on the distinctive features of the Chinese managerial forewords. It was found that the Chinese messages often began with thanks, whereas this did not occur in the English texts, which immediately began to review the year. Compared with the English statements, the Chinese messages were more politically salient. For example, commercial and political slogans tended to merge in the Chinese business discourse. When referring to the company, the Chinese messages tended to use nonperson forms, while the English texts preferred the 'institutional we'; both options can be seen as a discursive strategy to construct authority. More generally, this case study showed that although a variety of approaches can be taken to investigate business writing, combining corpus linguistics with discourse analysis can offer valuable insights.

\section{Conclusion}

This chapter has explored Chinese business communication by reviewing existing studies of Chinese business discourse and presenting a case study of executive messages using corpusassisted discourse analysis. As a relatively nascent field of study in business communication research, Chinese business communication has been gaining momentum over the past decades, not least because China's strong economic growth has translated into increasing intracultural and intercultural business interactions.

However, against the backdrop of the fast-changing business environment, few historical studies exist in this area, especially those that examine diachronic changes in the Chinese business discourse. Therefore, it would be beneficial to explore the influence of ecommerce on various types of business communication, such as written conversations. This 
aspect has been somewhat overlooked, at least partly due to a perceived novelty of the form. Another potential line of future research is the use of Chinese as a medium for intercultural business communication, especially for L2 Chinese businesspersons, because it has received little attention from scholars to date. Given the dearth of research in these areas, further empirical investigation and theorization are required to fully explore Chinese business communication and its impact on the modern business world.

\section{References}

\section{English References}

Bargiela-Chiappini, F., Nickerson, C. and Planken, B. (2013) Business Discourse, Basingstoke, UK: Palgrave Macmillan.

Baym, G. (2000) 'Constructing moral authority: We in the discourse of television news', Western Journal of Communication 64(1): 92-111.

Brown, P. and Levinson, C. S. (1987) Politeness: Some Universals in Language Usage (reissue in 1987 ed.), Cambridge: Cambridge University Press.

Chang, M. L. M. (2016) Face and Face Practices in Chinese Interaction: A Study in Interactional Pragmatics, London: Equinox.

Chang, W. L. M. and Haugh, M. (2013) 'Face in Taiwanese business interactions: from emic concepts to emic practices', in Y. Pan and D. Kádár (eds) Chinese Discourse and Interaction: Theory and Practice, London: Equinox.

Cheung, M. (2011) 'Sales promotion communication in Chinese and English: A thematic analysis', Journal of Pragmatics 43(4): 1061-1079.

De Groot, E. B., Korzilius, H., Nickerson, C. and Gerritsen, M. (2006) ‘A corpus analysis of text themes and photographic themes in managerial forewords of Dutch-English 
and British annual general reports', IEEE Transactions on Professional Communication 49(3): 217-235.

Du Babcock, B. and Babcock, R. D. (1996) 'Patterns of expatriate-local personnel communication in multinational corporations', The Journal of Business Communication 33(2): 141-164.

Fortune. (2017) Sinopec Group. Retrieved from http://fortune.com/global500/sinopecgroup/

Grice, H. P. (1975) 'Logic and conversation', in P. Cole and J. L. Morgan (eds) Syntax and Semantics: Speech Acts (Vol. 3), New York: Academic Press.

Halliday, M. (1994) An Introduction to Functional Grammar, London: Edward Arnold.

Inc. (2017) Annual reports. In Inc. Enclycopedia. Retrieved July 21, 2017, from https://www.inc.com/encyclopedia/annual-reports.html

Kirkpatrick, A. (1993) 'Information sequencing in Modern Standard Chinese in a genre of extended spoken discourse', Text - Interdisciplinary Journal for the Study of Discourse 13(3): 423-454.

Leech, G., Rayson, P. and Wilson, A. (2001) Word Frequencies in Written and Spoken English: Based on the British National Corpus, London: Routledge.

Li, W., Zhu, H. and Li, Y. (2001a) 'Conversational management and involvement in Chinese-English business talk', Language and Intercultural Communication 1(2): 135-150.

Li, W., Zhu, H. and Li, Y. (2001b) 'Interpersonal harmony and textual coherence in Chinese business interaction', Multilingua, 20(3): 285-311.

Linguistic Politeness Research Group (Ed.). (2011) Discursive Approaches to Politeness, Berlin: Walter de Gruyter.

Partington, A. (2008) 'The armchair and the machine: Corpus-assisted discourse 
Research', in C. Taylor Torsello, K. Ackerley and E. Castello. (eds) Corpora for University Language Teachers, Bern: Peter Lang.

Planken, B. (2005) 'Managing rapport in lingua franca sales negotiations: A comparison of professional and aspiring negotiators', English for Specific Purposes 24(4): 381400.

Qian, Y. \& Tian, H. (2014). A decade of change in China: A corpus-based discourse analysis of ten government work reports. In Q. Cao, H. Tian \& P. Chilton. (Eds.). Discourse, Politics and Media in Contemporary China (pp. 77-96). Amsterdam: John Benjamins.

Richard, E. M. and McFadden, M. (2016) 'Saving Face: Reactions to Cultural Norm Violations in Business Request Emails', Journal of Business and Psychology 31(2): 307-321.

Scollon, R., Scollon, S. W. and Jones, R. H. (2011) Intercultural Communication: A Discourse Approach, Oxford: Wiley.

Scott, M. (2009) 'In search of a bad reference corpus', in D. Archer (ed) What's in a Word-List? Investigating Word Frequency and Keyword Extraction, Surrey, UK: Ashgate.

Shell. (2013) Annual Report and Form 20-F 2012. Retrieved from http://reports.shell.com/annual-report/2012/servicepages/welcome.php

Swales, J. (1990) Genre Analysis: English in Academic and Research Settings, Cambridge: Cambridge University Press.

Wang, W. (2004) 'A contrastive analysis of letters to the editor in Chinese and English', Australian review of applied linguistics 27(1): 72-88.

Yeung, L. N. (1997) 'Polite requests in English and Chinese business correspondence in Hong Kong', Journal of Pragmatics 27(4): 505-522.

Zhu, Y. (2000) 'Rhetorical moves in Chinese sales genres, 1949 to the present', The Journal of Business Communication 37(2): 156-172. 
Zhu, Y. (2005) Written Communication across Cultures: A Sociocognitive

Perspective on Business Genres, Amsterdam: John Benjamins.

Zhu, Y. (2013) 'A cross-cultural analysis of English and Chinese business faxes: A genre perspective', Ibérica 26: 35-54.

Zhu, Y. and Hildebrandt, H. W. (2013) 'Effective Persuasion of International Business Sales Letters', Management International Review 53(3): 391-418.

Zhu, Y. and Li, L. (2009) 'China', in F. Bargiela-Chiappini (ed) Handbook of Business Discourse, Edinburgh: Edinburgh University Press.

\section{Chinese References}

Sinopec 中国石化 (2013) 中国石化 2012 年度報告 (2012 Annual Report). Retrieved from http://big5.sinopec.com/listco/Resource/Pdf/AnnualReport2012.pdf

Tang, Shuhua 唐树华 and Li, Xiaokang 李晓康 (2013) ‘商务话语研究的困境和趋 势 一一论我国商务话语研究目的与方法的冲突性及潜在突破性, (Dilemmas and trends of business discourse research - a discussion of the conflicts between our country's business discourse research purposes and methods and the potential way forward), 外语世界(Foreign Language World) 4: 11-18.

The Fifth Plenum of the 17th Central Committee of the Communist Party of China 中 国共产党第十七届中央委员会第五次全体会议 (2010) 中共中央关于制定国民经济和社 会发展第十二个五年规划的建议 (Outline of the 13th five-year plan for the national economic and social development of the people's republic of china). Retrieved from http://www.ndrc.gov.cn/

Xiao, Yuping 校玉萍 (2011) ‘国际商务电子邮件中请求策略的语用研究’ (A pragmatic analysis of the requesting strategies in international business emails), 外语教学 (Foreign Language Education) 32(6): 35-39. 
Zhang, Zongyuan 张宗原 (2006) ‘国际商务应用文的历史沿革’ (The historical development of international business writing), 国际商务研究(International Business Studies) 4: 57-61. 